\title{
PENGEMBANGAN RANCANGAN KERANGKA STANDARDISASI DAN PERSYARATAN PENGUJIAN SNI RADAR HUJAN DI INDONESIA
}

\author{
Designing Framework for Standardization and Testing Requirements \\ of Rain Radar in Indonesia
}

\author{
Hogan Eighfansyah Susilo dan Amy Reimessa² \\ 1,2Lembaga Penerbangan dan Antariksa Nasional, Jakarta \\ E-mail: hogan.eighfansyah@lapan.go.id
}

\begin{abstract}
Abstrak
Indonesia merupakan negara tropis yang memiliki curah hujan tinggi sehingga sering terjadi bencana hidrometeorologi seperti banjir dan tanah longsor. Oleh karena itu, diperlukan alat deteksi dini memantau intensitas atau curah hujan secara simultan salah satunya radar hujan. Untuk melindungi produk radar hujan dalam negeri dan melihat model yang sesuai untuk komersialisasi teknologi radar hujan, maka perlu dikembangkan Standar Nasional Indonesia (SNI) radar hujan. Pengembangan kerangka standar memiliki tantangan tersendiri. Terutama untuk mengidentifikasi langkah apa yang diperlukan untuk mengembangkan standar baru. Dalam penelitian ini digunakan pendekatan FACTS (Framework for Analysis, Comparison, and Testing of Standard) dan SEM (Structural Equation Model) dalam analisisnya. Tujuan dari penelitian ini adalah untuk membuat rekomendasi kerangka desain standar radar hujan. Selain itu, SEM digunakan untuk mencari dan memvalidasi model yang sesuai untuk komersialisasi radar hujan. Hasil kajian didapatkan 5 parameter utama standar yang dibutuhkan stakeholder yaitu spesifikasi sistem radar hujan, cara uji, kalibrasi dan perawatan, kriteria lokasi, serta kendali dan pemantauan sistem jarak. Parameter-parameter tersebut memiliki pengaruh signifikan terhadap tujuan standardisasi, sehingga dapat menjadi acuan dalam penyusunan standar.
\end{abstract}

Kata kunci: SEM, FACTS, Standardisasi, Radar, Cuaca, Hujan.

\begin{abstract}
Indonesia is a tropical country that has high rainfall so that hydro-meteorological disasters such as floods and landslides often occur. Because early detection tools are needed to monitor the intensity of rainfall simultaneously, one of which is rain radar. To protect domestic rain radar products and see which models are suitable for the commercialization of rain radar technology, it is necessary to develop the Indonesian National Standard (SNI) for rain radar. The development of a design framework for standards has its challenges. Mainly to identify what steps are required to develop a new standard. In this study, the FACTS approach (Framework for Analysis, Comparison, and Testing of Standards) and SEM (Structural Equation Model). The purpose of this study is to make recommendations for a standard rain radar design framework. Also, SEM is used to search and validate suitable models for rain radar commercialization. The results of the study obtained 5 main parameters needed by stakeholders, namely the rain radar system specifications, test methods, calibration and maintenance, location criteria, and distance system control and monitoring. These parameters have a significant influence on the objectives of standardization so that they can become a reference in standard development.
\end{abstract}

Key word: SEM, FACTS, Standardization, Radar, Weather, Rain.

\section{PENDAHULUAN}

Indonesia merupakan negara tropis yang memiliki curah hujan tinggi. Menurut data dari Badan Klimatologi dan Geofisika (BMKG) rata curah hujan di Wilayah Indonesia sebesar 200 - 300 $\mathrm{mm}$ /hari bahkan awal tahun 2020 tercatat curah hujan mencapai $380 \mathrm{~mm} /$ hari (BMKG, 2020). Curah hujan yang tinggi menyebabkan beberapa daerah di Indonesia sering terjadi bencana hidrometeorologi seperti banjir dan tanah longsor. Berdasarkan data Badan Nasional Penanggulangan Bencana (BNPB) sampai tahun 2019 telah terjadi 12.801 kasus bencana banjir dan tanah longsor (BNPB, 2019).

Oleh karena itu, diperlukan adanya deteksi dini terhadap faktor-faktor penyebab banjir dan tanah longsor. Salah satu cara adalah pemantauan intensitas hujan yang terjadi di wilayah Indonesia secara simultan. 
Berbagai teknologi telah dikembangkan untuk pemantauan intensitas hujan, diantaranya radar cuaca. Radar cuaca merupakan salah satu alternatif dalam untuk peringatan dini terhadap bencana tersebut. Radar cuaca merupakan doppler radar yang dapat mendeteksi partikel hujan, partikel es maupun wind shear sehingga dapat memonitoring cuaca (Davini,2012). Saat ini radar cuaca yang ada di Indonesia masih didominasi oleh produk dari luar negeri. Untuk bersaing dengan produk tersebut dan seiring dengan pekembangan industri radar di dalam negeri terdapat inovasi berupa radar hujan. Kemampuan radar ini dalam mematau sebaran hujan dan intensitasnya dapat menjadi solusi untuk peringatan dini banjir dan tanah longsor.

Radar hujan merupakan radar berbasis $\mathrm{x}$ band yang dirancang untuk memantau sebaran spasial curah hujan dan memperkirakan intensitasnya. Radar ini dapat memantau curah sejauh 44 Km (Sinatra, 2014).

Untuk melindungi produk radar hujan dalam negeri dan melihat model yang sesuai untuk komersialisasi teknologi radar hujan, maka perlu dikembangkan Standar Nasional Indonesia (SNI) radar hujan. Berdasarkan Standardisasi Undang-Undang Nomor 20 Tahun 2014 tentang Standardisasi dan Penilaian Kesesuaian, pengembangan standar atau standardisasi dapat melindungi produsen dan konsumen dalam menjaga mutu produk yang dibuat atau digunakan. Pengembangan standar penting dikarenakan standar yang ditetapkan oleh pemerintah dapat mendorong pelaku usaha untuk mengembangkan produknya sesuai dengan standar dan meningkatkan daya saing produk di pasar global.

Penelitian ini bertujuan untuk mengidentifikasi parameter radar hujan yang dibutuhkan oleh stakeholder sebagai bahan rancangan standar. Dalam Identifikasi parameter ini digunakan pendekatan FACTS (Framework for Analysis, Comparison, and Testing of Standard) (Prianjani, 2017). Selain itu, hasil identifikasi parameter yang akan digunakan, sebagai referensi standar perlu diverifikasi dan diuji validitasnya dengan menggunakan pendekatan statistik SEM (Structural Equation Model) dan hasil FGD (Forum Group Discussion).

\section{TINJAUAN PUSTAKA}

\subsection{Standardisasi}

Standardisasi merupakan proses pembuatan standar yang menurut UU No. 20 Tahun 2014 sebagai sebuah rangkain proses dalam merencanakan, merumusakan, menetapkan, menerapkan, memberlakukan, memelihara dan mengawasi standar secara tertib dan melibatkan semua pemangku kepentingan sedangkan standar sendiri tersebut merupakan suatu spesifikasi teknis yang dibakukan atau dapat berupa tata cara dan metode yang disusun berdasarkan konsensus dari semua pihak dengan memperhatikan syarat-syarat keselamatan, keamanan, kesehatan, lingkungan hidup, perkembangan ilmu pengetahuan dan teknologi, serta pengalaman, perkembangan masa kini dan masa yang akan datang untuk memperoleh manfaat yang sebesar-besarnya (ISO/IEC Guide 2:2004). Dalam perumusan standar harus memenuhi beberapa prinsip yaitu konsensus, melibatkan semua stakeholder, terbuka, kebaruan dan juga koheren.

\subsection{Radar Hujan}

Radar hujan merupakan radar yang dikembangkan dari radar X- Band yang biasa digunakan untuk navigasi kapal (Nugroho,2015). Seperti layaknya radar biasa, radar ini memanfaatkan energi yang dipancarkan radar dan dipantulkan benda yang dalam kasus ini adalah partikel tetes hujan. Semakin besar tetes partikel hujan untuk satuan sampel volume maka semakin berar energi yang dipantulkan dan ditangkap oleh radar sebagai hasil deteksi curah hujan yang terjadi (Nugroho,2016). Radar hujan ini dapat memantau curah hujan sejuah $44 \mathrm{Km}$. Radar hujan ini dikembangkan oleh Pusat Sains dan Teknologi Atmosfer LAPAN dan telah diproduksi oleh beberapa perusahaan dan dipasang dibeberapa wilayah oleh BMKG.

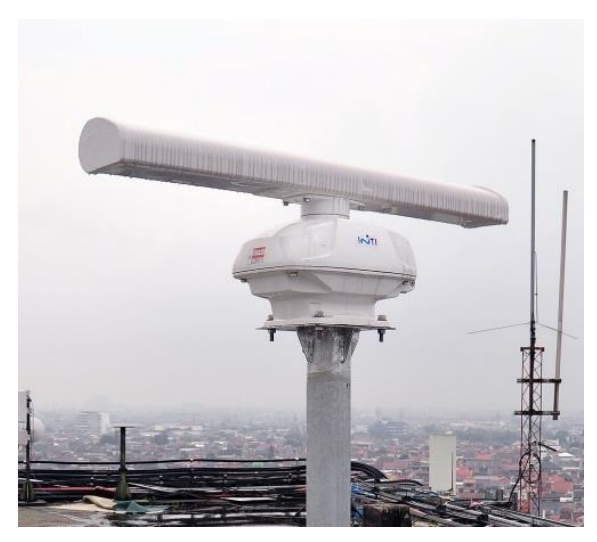

Gambar 1. Radar hujan

\subsection{FACT (Framework for Analysis, Comparison, and Testing of Standard)}

Metode FACT merupakan metode yang dikembangkan oleh National Institute of Standards and Technology (NIST) dalam pendekatan untuk pengembangan standar dan implementasi standar. Pendekatan FACTS ini dapat diaplikasikan pada setiap tahapan dalam 
siklus standar yaitu: (1) pengembangan standar; (2) implementasi standar; (3) Pemeliharaan standar, dan pendekatan ini dapat diterapkan dalam setiap siklus hidup standar secara terpisah (Witherell, 2013). Dalam pengembangan standar, pendekatan ini mempertimbangkan kepentingan dari seluruh stakeholder. Konsep FACTS ini sesuai dengan prinsip pengembangan standar dari BSN yaitu konsensus. Prinsip konsensus ini mempertimbangkan pendapat atau persyaratan stakeholder yang tidak berpihak pada pihak tertentu untuk mengambil keputusan (Sutopo, 2018). Pendekatan ini juga menyediakan Framework untuk menganalisa, membandingkan dan menguji standar dengan cara strukturisasi dan formalisasi informasi melalui Zachman framework. Zachman framework merupakan kerangka yang digunakan untuk memperoleh informasi menggunakan kerangka tanya $5 \mathrm{~W} 1 \mathrm{H}$ (Witherell, 2013).

\subsection{SEM (Structural Equation Model)}

Structural Equation Model (SEM) merupakan metode yang dapat menjelaskan, memperkirakan dan menguji secara menyeluruh hubungan antar variabel yang ada dalam penelitian. SEM dapat digunakan untuk memeriksa dan menverifikasi suatu model. Sehingga, syarat utama dalam SEM adalah membangun suatu model hipotesis yang terdiri dari model struktural dan model pengukuran dalam bentuk diagram jalur yang berdasarkan justifikasi teori (Suhr, 2006). SEM adalah merupakan sekumpulan teknik-teknik statistik yang memungkinkan pengujian sebuah rangkaian hubungan secara simultan. Hubungan itu dibangun antara satu atau beberapa variable independen (Santoso, 2015).

Terdapat 2 model dalam SEM, yaitu model pengukuran dan model struktural. Model pengukuran adalah bagian dari model SEM yang menggambarkan hubungan antara variabel laten dengan indikator-indikatornya. Sedangkan model struktural menggambarkan hubungan antar variabel-variabel laten atau antar variabel eksogen dengan variabel laten. Contoh model SEM terdapat pada Gambar 2.

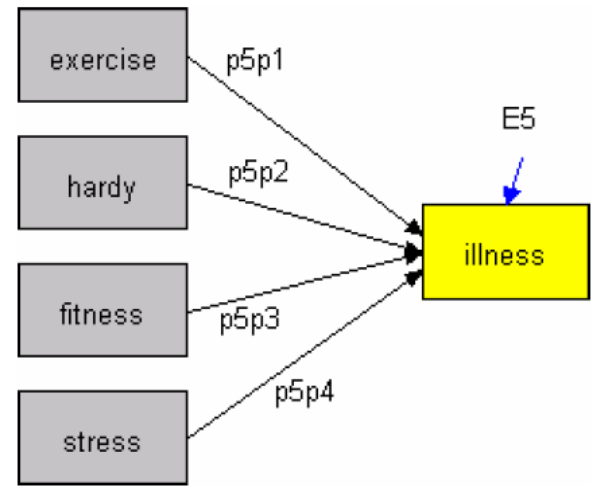

Gambar 2. Contoh model Structural Equation Model (SEM)

Sumber: (Suhr, 2006).

\section{METODE PENELITIAN}

Penelitian ini menggunakan pendekatan FACTS atau Framework for Analysis Comparison and Testing Standard. Terdapat 4 tahap utama dalam pendekatan FACTS: (1) Analisis Stakeholder, (2) Analisis Teknis, (3) Perbandingan Standar, dan (4) Pengujian Standar.

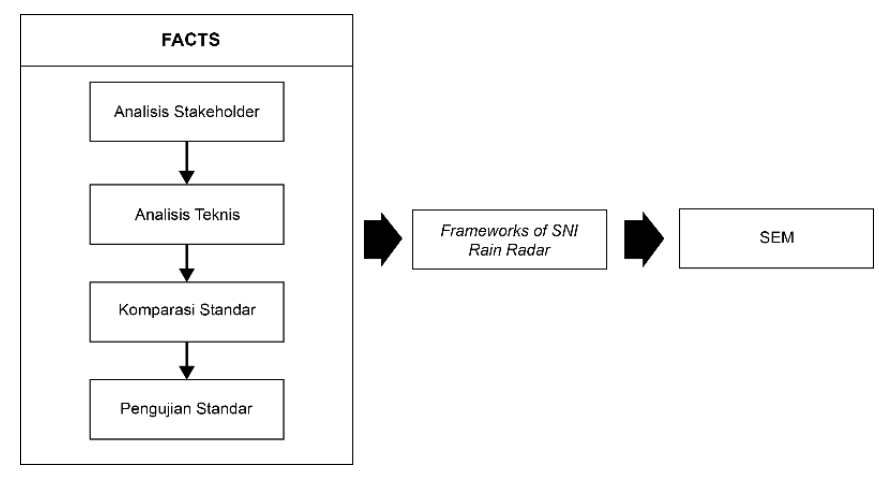

Gambar 3. Tahapan penelitian

Tahap pertama analisis stakeholder dilakukan studi literature untuk mengumpulkan data spesifikasi radar hujan yang dibutuhkan berdasarkan jurnal yang ada. Selain itu, identifikasi stakeholder yang terlibat yaitu produsen radar cuaca dan pengguna melalui interview. Pada tahap kedua analisis teknis dilakukan menghubungkan kebutuhan stakeholder dengan teknis. Keluaran dari tahapan ini berupa spesifikasi teknis berdasar kebutuhan stakeholder radar hujan. Tahap ketiga merupakan tahap komparasi spesifikasi dari standar internasional yang ada seperti World Meteorological Organization (WMO) dan ISO dengan spesifikasi hasil analisis teknis. Tahap keempat merupakan kombinasi dari hasil tahap sebelumnya dengan standar internasional yang ada. Hasil tersebut digunakan sebagai saran kerangka parameter dalam penyunan standar nasional Indonesia (SNI) radar hujan. Pada tahap 
pengujian standar ini dilakukan pengujian dengan memverifikasi kerangka standar yang dibuat. Verifikasi ini menggunakan SEM yang akan melihat hubungan kerangka dengan tujuan standardisasi, apakah sesuai dengan kebutuhan stakeholder. Kemudian pengujian diakhiri dengan validasi dengan dilakukan pertemuan FGD (Forum Group Discussion) dengan stakeholder yang terkait.

\section{HASIL DAN PEMBAHASAN}

4.1 FACTS (Framework for Analysis, Comparison and Testing standards)

Seperti yang ditunjukan pada gambar 3. Dalam pendekatan FACTS terdiri dari beberapa tahapan yaitu analisis stakeholder, analisis teknis, komparasi standar dan pengujian standar.

\subsubsection{Analisis Stakeholder}

Pada tahap ini, dilakukan identifikasi stakeholder yang terlibat dan pengumpulan data berdasarkan kebutuhan nasional. Kebutuhan stakeholder diperoleh dengan studi literatur dan wawancara.

Stakeholder yang dilibatkan dalam standar radar hujan terdiri dari perwakilan Pemerintah, konsumen, produsen, laboratorium uji dan R\&D radar hujan. Dari hasil pengumpulan data didapat beberapa persyaratan yang perlu dalam standar ini Berikut beberapa persyaratan berdasarkan kebutuhan stakeholder pada Tabel 1.

Tabel 1 Persyaratan berdasarkan kebutuhan stakeholder

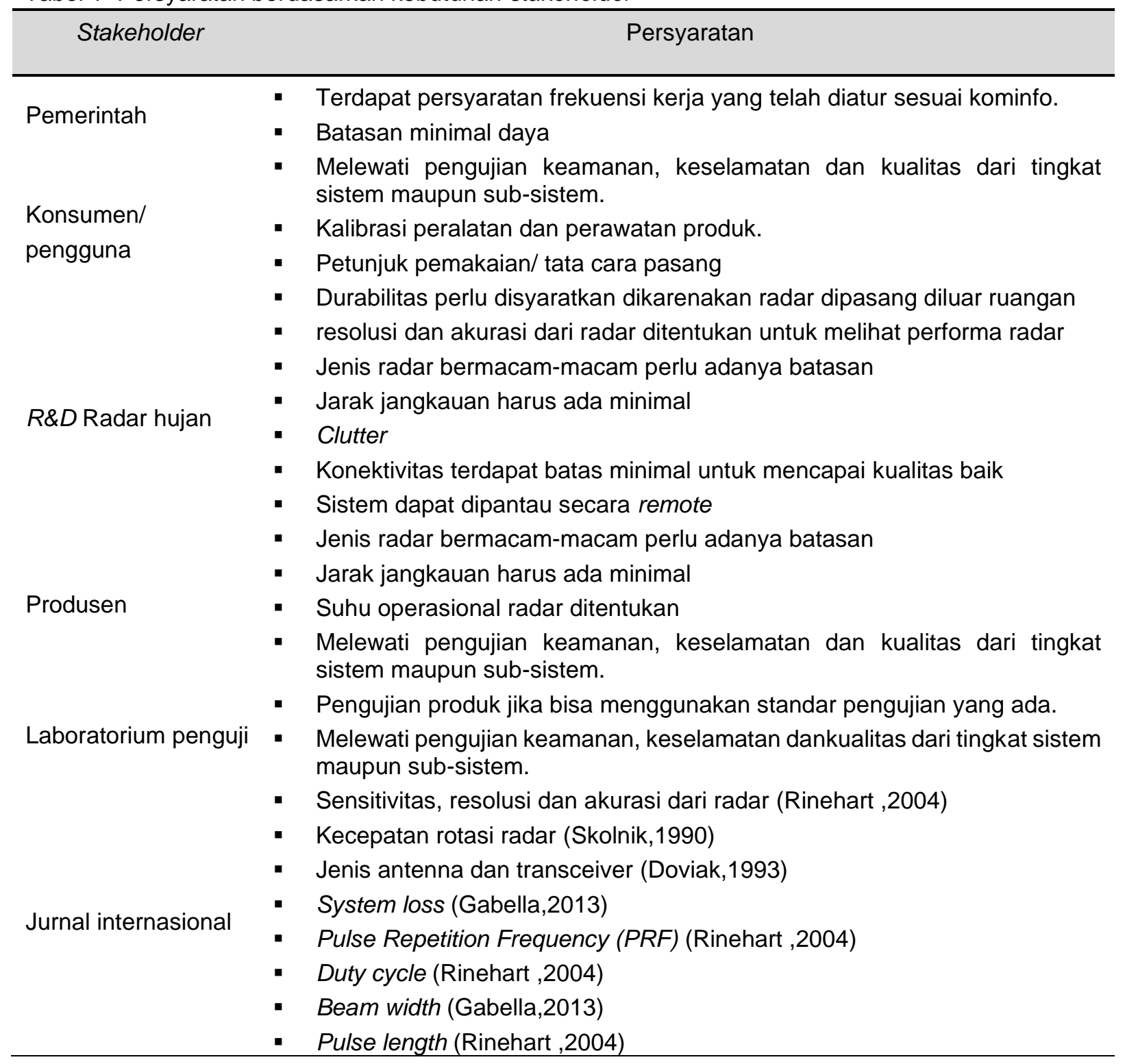




\subsubsection{Analisis Teknis}

Pada tahap analisis ini, persyaratan stakeholder dari tahap sebelumnya, diubah menjadi bahasa teknis dengan Zachman
Framework. Analisis kebutuhan teknis juga dilakukan untuk mencegah terjadinya duplikasi aspek teknis dari hasil data atau informasi yang diperoleh. Hasil analisis teknis di tunjukkan pada Tabel 2.

Tabel 2. Hasil analisis teknis radar hujan

\begin{tabular}{|c|c|c|}
\hline Persyaratan & Analisis teknis & \multirow{14}{*}{ 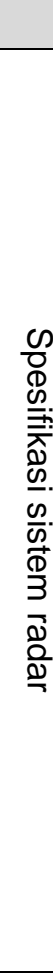 } \\
\hline $\begin{array}{l}\text { - Terdapat persyaratan frekuensi kerja yang } \\
\text { telah diatur sesuai kominfo. }\end{array}$ & $\begin{array}{l}\text { Pembatasan frekuensi kerja yang } \\
\text { digunakan }\end{array}$ & \\
\hline - Batasan minimal daya & Persyaratan power output radar & \\
\hline - Sensitivitas, Resolusi dan akurasi dari radar & Sensitivitas, Resolusi, Akurasi & \\
\hline - Jarak jangkauan & Luas cakupan wilayah & \\
\hline - Konektivitas & Kecepatan transfer data & \\
\hline $\begin{array}{l}\text { - Jenis antenna } \\
\text { - } \quad \text { Beam width } \\
\text { - } \quad \text { System loss } \\
\end{array}$ & Spesifikasi antena & \\
\hline - Kecepatan rotasi radar & Kecepatan rotasi radar & \\
\hline - Transceiver & Jenis Transmitter & \\
\hline - Pulse Repetition Frequency (PRF) & Pulse Repetition Frequency (PRF) & \\
\hline - Duty cycle & Duty cycle & \\
\hline - Pulse length & Pulse length & \\
\hline - Suhu operasional & Suhu operasional & \\
\hline - Durabilitas & Jenis Enclosure & \\
\hline $\begin{array}{l}\text { - Pengujian produk jika bisa menggunakan } \\
\text { standar pengujian yang ada. } \\
\text { - Melewati pengujian keamanan, keselamatan } \\
\text { dankualitas dari tingkat sistem maupun sub- } \\
\text { sistem. }\end{array}$ & Cara uji & \\
\hline $\begin{array}{l}\text { - Kalibrasi peralatan dan perawatan produk. } \\
\text { - Clutter }\end{array}$ & Kalibrasi dan perawatan & \\
\hline - Petunjuk pemakaian/ tata cara pasang & Tata cara pasang dan kriteria I & \\
\hline - Pengendalian sistem secara remote & Kendali dan pemantauan sist & \\
\hline
\end{tabular}

Hasil analisis teknis ini menghasilkan beberapa parameter teknis utama yang diatur yaitu spesifikasi sistem radar hujan, cara uji, kalibrasi dan perawatan, kriteria lokasi, serta kendali dan pemantauan sistem jarak. Parameter spesifikasi system radar hujan ini diuraikan menjadi parameter yang lebih rinci.

\subsubsection{Komparasi Standar}

Pada tahap komparasi standar dilakukan dengan membandingkan persyaratan teknis yang ada dalam standar yang ada seperti standar internasional dengan kebutuhan teknis stakeholder sehingga diketahui persyaratan teknis apa yang belum diatur maupun yang tumpang tindih dalam standar (Pratiwi,2018).

Terdapat 2 standar yang dipilih untuk dibandingkan dan disikusikan oleh stakeholder yaitu ISO 19926-1:2019 dan WMO No.8 Chapter 7 CIMO Guide 2. Hasil perbandingan standar dapat dilihat pada Tabel 3. 
Tabel 3. Perbandingan kerangka standar dengan standar acuan

\begin{tabular}{|c|c|c|c|}
\hline Persyaratan teknis & Standar radar hujan & $\begin{array}{l}\text { ISO 19926- } \\
1: 2019 \text { (en) }\end{array}$ & $\begin{array}{c}\text { WMO No.8 } \\
\text { Chapter } 7 \text { CIMC } \\
\text { Guide } 2\end{array}$ \\
\hline Frekuensi kerja & Klausul 3.2.2.1 & Klausul 5.1 & Klausul 7.6.2 \\
\hline Minimum Power output & Klausul 3.3 & - & - \\
\hline Resolusi & Klausul 4.4 & Klausul 6.2.2 & Klausul 7.6.6 \\
\hline Sensitivitas & - & Klausul 6.2.1 & Klausul 7.6.3 \\
\hline Akurasi & - & Klausul 6.2.4 & Klausul 7.2.1 \\
\hline Cakupan wilayah & Klausul 3.3 & Klausul 9.4 & - \\
\hline Kecepatan transfer data & Klausul 8.3 & Klausul 9.3 & - \\
\hline Spesifikasi antenna & Klausul 3.2.2.2 & Klausul 5.2.3.1 & Klausul 7.6.6 \\
\hline Kecepatan rotasi radar & Klausul 3.2.2.2 & Klausul 6.3.4 & Klausul 7.6.8 \\
\hline Jenis Transmitter & Klausul 3.2.2.3 & Klausul 5.2.3.3 & Klausul 7.6.8 \\
\hline Pulse Repetition Frequency (PRF) & Klausul 3.2.2.3 & Klausul 5.2.3.3 & Klausul 7.6.5 \\
\hline Duty cycle & Klausul 3.2.2.3 & Klausul 5.2.3.3 & - \\
\hline Pulse length & Klausul 3.2.2.3 & Klausul 5.2.3.3 & Klausul 7.6.4 \\
\hline Suhu operational & Klausul 4.3 & - & - \\
\hline Jenis Enclosure & Klausul 3.2.2.8 & - & - \\
\hline Cara uji & Klausul 5 & Annex A & - \\
\hline Kalibrasi dan perawatan & Klausul 6 & Klausul 7 & Klausul 7.7 \\
\hline Tata cara pasang dan kriteria lokasi & Klausul 7 & Klausul 9 & Klausul 7.8 \\
\hline Kendali dan pemantauan sistem & Klausul 8 & Klausul 9.3 & Klausul 7.8.2 \\
\hline
\end{tabular}

Hasil perbandingan menunjukan bahwa sebagian besar parameter/persyaratan teknis dari standar radar hujan telah memenuhi standar acuan yang telah ada. Namun terdapat beberapa persyaratan yang belum diatur maupun yang diatur lebih pada standar radar hujan dibanding standar acuan, contohnya pada persyaratan sensitivitas dan akurasi yang tidak diatur secara rinci. Sedangkan untuk persyaratan yang diatur lebih rinci yaitu pada persyaratan yaitu pada power output, suhu operasional dan jenis enclosure.

\subsubsection{Pengujian Standar}

Tahap pengujian standar ini dilakukan pengujian kerangka standar dari hasil tahap sebelumnya yaitu komparasi standar. Hasil komparasi standar dapat digunakan untuk membuat rancangan kerangka standar. Rancangan kerangka standar selanjutnya dapat digunakan sebagai bahan kuesioner untuk dibagikan kepada stakeholders pada FGD untuk validasi kapabilitas nasional.
Tabel 4 Hasil validasi persyaratan terhadap kebutuhan stakeholder dan kapabilitas nasional.

\begin{tabular}{|c|c|c|c|c|c|}
\hline $\begin{array}{l}\text { Persyaratan } \\
\text { teknis }\end{array}$ & $A$ & $\mathrm{~B}$ & C & $\mathrm{D}$ & $\mathrm{E}$ \\
\hline Frekuensi kerja & $\mathrm{Ya}$ & * & $\mathrm{Ya}$ & $\mathrm{Ya}$ & * \\
\hline Power output & $\mathrm{Ya}$ & * & Ya & $\mathrm{Ya}$ & * \\
\hline Resolusi & $\mathrm{Ya}$ & Ya & Ya & $\mathrm{Ya}$ & * \\
\hline Cakupan wilayah & $\mathrm{Ya}$ & $\mathrm{Ya}$ & $\mathrm{Ya}$ & $\mathrm{Ya}$ & * \\
\hline $\begin{array}{l}\text { Kecepatan } \\
\text { transfer data }\end{array}$ & * & * & $\mathrm{Ya}$ & * & * \\
\hline Spesifikasi antena & * & * & $\mathrm{Ya}$ & $\mathrm{Ya}$ & * \\
\hline $\begin{array}{l}\text { Kecepatan rotasi } \\
\text { radar }\end{array}$ & * & * & $\mathrm{Ya}$ & $\mathrm{Ya}$ & * \\
\hline Jenis Transmitter & * & * & $\mathrm{Ya}$ & $\mathrm{Ya}$ & * \\
\hline $\begin{array}{l}\text { Pulse Repetition } \\
\text { Frequency (PRF }\end{array}$ & * & * & $\mathrm{Ya}$ & $\mathrm{Ya}$ & * \\
\hline Duty cycle & * & * & $\mathrm{Ya}$ & $\mathrm{Ya}$ & * \\
\hline Pulse length & * & * & $\mathrm{Ya}$ & Ya & * \\
\hline Suhu operatioanl & $\mathrm{Ya}$ & * & $\mathrm{Ya}$ & $\mathrm{Ya}$ & * \\
\hline Jenis Enclosure & $\mathrm{Ya}$ & $\mathrm{Ya}$ & $\mathrm{Ya}$ & $\mathrm{Ya}$ & * \\
\hline Cara uji & $\mathrm{Ya}$ & * & $\mathrm{Ya}$ & $\mathrm{Ya}$ & $\mathrm{Ya}$ \\
\hline $\begin{array}{l}\text { Kalibrasi dan } \\
\text { perawatan }\end{array}$ & $\mathrm{Ya}$ & $\mathrm{Ya}$ & $\mathrm{Ya}$ & * & $\mathrm{Ya}$ \\
\hline
\end{tabular}




\begin{tabular}{|c|c|c|c|c|c|}
\hline $\begin{array}{l}\text { Persyaratan } \\
\text { teknis }\end{array}$ & $A$ & B & C & $\mathrm{D}$ & $E$ \\
\hline $\begin{array}{l}\text { Tata cara pasang } \\
\text { dan kriteria lokasi }\end{array}$ & * & $\mathrm{Ya}$ & $\mathrm{Ya}$ & * & * \\
\hline $\begin{array}{l}\text { Kendali dan } \\
\text { pemantauan } \\
\text { sistem }\end{array}$ & * & $\mathrm{Ya}$ & $\mathrm{Ya}$ & * & * \\
\hline \multicolumn{6}{|l|}{ A: Pemerintah } \\
\hline \multicolumn{6}{|c|}{ B: Konsumen/Pengguna } \\
\hline \multicolumn{6}{|c|}{ C: R\&D Radar hujan } \\
\hline \multicolumn{6}{|c|}{ D: Produsen } \\
\hline \multicolumn{6}{|c|}{ E: Laboratorium penguji } \\
\hline * : Dipertimbangkan & & & & & \\
\hline
\end{tabular}

\subsection{SEM (Structural Equation Model)}

Metode SEM ini digunakan untuk memverifikasi seberapa kuat pengaruh indikator ataupun parameter kebutuhan stakeholder yang telah disusun dalam kerangka SNI radar hujan ini terhadap tujuan standardisasi. Pada Gambar 4 merupakan hasil model SEM dari kerangka standar untuk verifikasi aspek standar yang memiliki pengaruh signifikan.

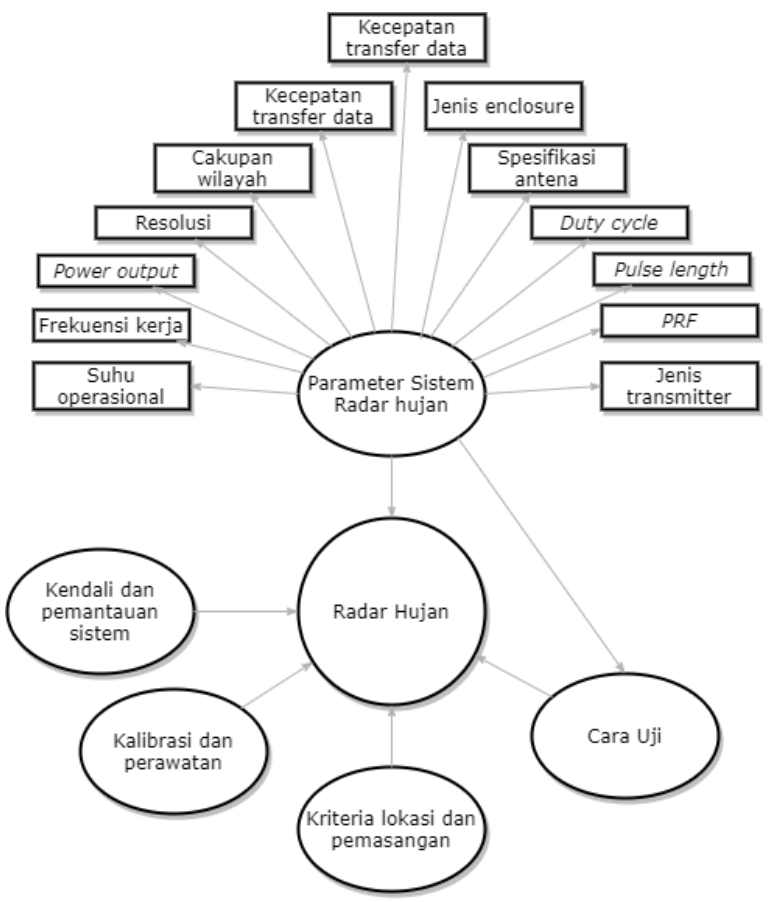

Gambar 4. Model SEM parameter SNI Radar Hujan.

Pada model tersebut dapat dilihat bahwa standar radar hujan dipengaruhi 5 indikator/parameter yaitu kendali dan pemantauan sistem, kalibrasi dan perawatan, kriterian lokasi dan pemasangan, cara uji serta parameter sistem radar hujan. Untuk indikator cara uji dipengaruhi juga oleh indikator sistem radar hujan dikarenakan variabel yang diuji sebagai tanda keberterimaan produk radar hujan yang diatur pada parameter sistem radar hujan.

\section{KESIMPULAN}

Berdasarkan kajian ini didapatkan parameter untuk kerangka Standar Nasional Indonesia (SNI) radar hujan serta kerangka proses verifikasinya. Terdapat 5 parameter utama sebagai usulan untuk standar radar hujan yaitu spesifikasi sistem radar hujan, cara uji, kalibrasi dan perawatan, kriteria lokasi, serta kendali dan pemantauan sistem jarak.

Selain itu, verifikasi dilakukan dengan menggunakan SEM didapatkan model dari kerangka standar SNI radar hujan. Dari hal tersebut diketahui 5 parameter utama yang memiliki pengaruh signifikan terhadap standardisasi, sehingga dapat menjadi acuan dalam penyusunan SNI.

Diharapkan dari hasil ini dapat memperkuat pengembangan Standar Nasional Indonesia (SNI) produk radar hujan di Indonesia, dengan tetap mengakomodir kebutuhan stakeholders dan perkembangan teknologi serta industri radar cuaca di Indonesia, dengan tetap mengakomodir kebutuhan di Indonesia. Di sisi lain, hasil kajian tersebut juga mempertegas spesifikasi teknis bagi produsen radar hujan di Indonesia guna meningkatkan daya saing produk yang menjadi acuan dalam perdagangan global di pasar internasional.

\section{UCAPAN TERIMA KASIH}

Terima kasih kepada manajemen puncak LAPAN, Pusat Inovasi dan Standar Penerbangan dan Antariksa LAPAN, Komite Teknis 49-02 sistem informasi dan akuisisi data keantariksaan dan pihak-pihak yang telah mendukung penelitian ini.

\section{DAFTAR PUSTAKA}

Badan Meteorologi, Klimatologi dan Geofisika. (2020). Buletin analisis curah hujan 2020. BMKG

Badan Nasional Penanggulangan Bencana. (2019). Data bencan alam di Indonesia tahun 1815 - 2019. Data Informasi Bencana Indonesia. BNPB. Diambil 25 April 2020

Davini P, Bechini R, Cremonini R and Cassardo C (2012) Radar-Based Analysis of Convective Storms over Northwestern Italy Atmosphere 3 33-58 
Doviak, R.J. and D.S. Zrnic, (1993) Doppler Radar and Weather Observations. Second edition, Academic Press, San Diego.

Fukao S dan Hamazu K, (2014). Radar for Meteorological and Atmospheric Observation, Springer.

Gabella M., Sartori M., Progin O., Germann U., (2013). Acceptance tests and monitoring of the next generation polarimetric weather radar network in Switzerland, Proc. IEEE Int. Conf. Electromagn. Adv. Appl., Torino, Italy, 211-214.

International Organization for Standardization. (2004). ISO/IEC Guide 2 Standardization and related activities - General vocabulary. ISO.

International Organization for Standardization. (2019). ISO 19926-1:2019(en) Meteorology - Weather radar - Part 1: System performance and operation. ISO.

Nugroho G A, Munir M M and Khairurrijal (2015). Computer-Based Marine Automatic Radar for Rain Detection Applied Mechanics and Materials 771 (2015) pp 9-12

Nugroho G A, Sinatra T, Awaludin A, Halimurrahman and Handiana D (2016). Hail Detection By a Low Cost Local Weather Radar Operated For Disaster Early Warning System Proceeding of The 7 Indonesian Japan Joint Scientific Symposium 2016

Pedersen L, Jensen N E, dan Madsen H (2010) Calibration of Local Area Weather RadarIdentifying Significant Factors Affecting the Calibration.Atmospheric Research, 97, 129-143.

Prianjani, D., Fahma, F., Sutopo, W., Nizam, M., Purwanto, A., Louhenapessy, B. B., \& Mulyono, A. B. (2017). The standard development for the National Standard of Indonesian (SNI) of the cell traction battery Lithium-ion Ferro phosphate secondarry for electric vehicles applications. 2nd International Conference of Industrial, Mechanical, Electrical, and Chemical Engineering, ICIMECE 2016, 213-218.

Pratiwi R A, Fahma F, Sutopo W, Pujianto E, Suprapto, Ayundyahrini M. (2018). Usulan Kerangka Standar Kursi Roda Manual Sebagai Acuan Penyusunan Standar Nasional Indonesia (SNI). Jurnal
Standardisasi Volume 20 Nomor 3, 207217.

Rahmawatie, B., Sutopo, W., Fahma, F., Purwanto, A., Nizam, M., Louhenapessy, B. B., \& Mulyono, A. B. (2017). Designing framework for standardization and testing requirements of battery management system for electric vehicle application. 4th International Conference on Electric Vehicular Technology (ICEVT), 7-12.

Rinehart, R.E., (2004). Radar for Meteorologists. 4th Edition, Rinehart Publishing.

Santoso, Singgih. (2015). Menguasai Statistik Multivariat. Jakarta: PT Elex Media Komputindo.

Savina M, (2011) The use of a cost-effective $x$ band weather radar in alphine region, ETH Zurich.

Sinatra T, Noersomadi, Nugroho G A and Trilaksono N J (2014) Characterizing the diurnal cycle of convective activity over the south of west java using doppler $x$-band radar observation The 4th international symposium for sustainable humanosphere (ISSH)-a forum of the humanosphere science school (HSS) 2014 ISSN:20889127

Skolnik, M.I. (ed.), (1990). Radar Handbook. McGraw-Hill, New York.

Suhr, D. (2006). The Basics of Structural Equation Modeling. University of Colorado

Sutopo, W., \& Kadir, E. A. (2018). Designing Framework for Standardization Case Study: Lithium-lon Battery Module in Electric Vehicle Application, 8(1), 220226.

Undang Undang (UU) No.20 Tahun 2014 tentang Standardisasi dan Penilaian Kesesuaian

Witherell, Paul; Rachuri, Sudarsan; Narayanan, Anantha dan Hyun Lee, Jae. (2013). FACTS: A Framework for Analysis, Comparison, and Testing of Standards. National Institute of Standards and Technology, United States.

World Meteorological Organization. (2014). WMO No.-8, Chapter 7, CIMO-Guide (http://library.wmo.int/opac/doc_num.php? explnum_id=3185). 